\section{Re: Ultralyd som integrert del av medisinstudiet}

I Tidsskriftet nr. 14-15/2016 legges det frem planer for integrering av ultralyd i undervisningen av medisinstudenter ved Universitet i Oslo (1). Som Gunnarsson og medarbeidere svarer i sin kommentar over, er dette på høy tid og en ønsket utvikling.

Når referanselisten leses virker det som at man ikke har sett til miljøer i Norge som har arbeidet med slik integrering i mange år. Geitung og Grøttum har blant annet referert til et arbeid fra 1997 (2), et arbeid som ble utført lenge før moderne utstyr så dagens lys. Dagens tilgjengelige utstyr senker terskelen for bruk betraktelig, slik at ovennevnte studies resultater fra nesten 20 år tilbake ikke er sammenlignbar med dagens situasjon.

I Trondheim har det blitt arbeidet med undervisning i ultralyd på medisinstudiet i mange år. Andersen og medarbeidere publiserte et slikt arbeid i 2014 (3), med bedre resultater enn vi oppnådde i eget arbeid med medisinstudenter fra Universitetet i Oslo (4). Sistnevnte var riktignok kun ultralyd av hjertet, men førstnevnte inkluderte også abdominale undersøkelser.

Ut fra egne erfaringer med undervisningsansvar for et helt LISkorps er det helt riktig å vektlegge den praktiske delen av en slik undervisning (5). Dessverre fjerner det ikke problemet med at en liten andel ikke er interesserte, men alle kan lære noe, og dette løftet er viktig for et langstrakt Norge med lang vei mellom spesialister.

\section{Vidar Ruddox}

vidar.ruddox@siv.no

Ingvild B. Norum

Vidar Ruddox (f. 1976) er ph.d. og konstituert overlege ved Sykehuset Vestfold.

Ingen oppgitte interessekonflikter.

Ingvild B. Norum (f. 1980) er konstituert overlege ved Sykehuset i Vestfold.

Ingen oppgitte interessekonflikter.

\section{Litteratur}

1. Geitung JT, Grøttum P. Ultralyd som integrert del av medisinstudiet. Tidsskr Nor Legeforen 2016; 136: 1192

2. Heilo $A$, Hansen $A B$, Holck $P$ et al. Ultrasound «electronic vivisection» in teaching of human anatomy for medical students. Eur J Ultrasound 1997; 5: 203-7.

3. Andersen GN, Viset A, Mjølstad OC et al. Feasibility and accuracy of point-of care pocket-size ultrasonography performed by medical students. BMC Med Educ 2014; 14: 156.

4. Stokke TM, Ruddox V, Sarvari SI et al. Brief group training of medical students in focused cardiac ultrasound may improve diagnostic accuracy of physical examination. J Am Soc Echocardiogr 2014; 27: 1238-46.

5. Ruddox V. Stokke TM, Edvardsen T et al. The diagnostic accuracy of pocket-size cardiac ultrasound performed by unselected residents with minimal training. Int J Cardiovasc Imaging 2013; 29: 1749-57.

\section{Re: Magnesiummangel og protonpumpehemmere}

Bruserud \& Hansen kommenterer to publiserte kasuistikker hvor protonpumpehemmere mistenkes å ha bidratt til alvorlige forløp med sykehusinnleggelse som følge av hypomagnesemi og oppfordrer til årvåkenhet for denne typen bivirkninger (1). Vi vil benytte anledningen til også å minne om meldeplikten for alvorlige legemiddelreaksjoner. For å sikre god kjennskap til legemidlenes bivirkningsprofil er det viktig at alvorlige legemiddelreaksjoner meldes selv om disse er kjente.

Da RELIS omtalte problemstillingen i 2011, var det kun mottatt to bivirkningsmeldinger med mistanke om hypomagnesemi på grunn av protonpumpehemmere i Norge (2). I 2013 ble det meldt ytterligere ett tilfelle, slik at det totale antallet meldte tilfeller direkte fra norsk helsepersonell nå er tre. Alle disse tre tilfellene ble meldt i Midt-Norge og gjaldt pasienter med et overforbruk av alkohol (selvstendig risikofaktor) (Søk i Den norske bivirkningsdatabasen i Statens legemiddelverk - 24.8.2016). Kasuistikkene beskrevet i Tidsskriftet utgjør således et viktig supplement og bidrar til utvidet kunnskap om hvilke pasientgrupper som er sårbare for å utvikle hypomagnesemi under behandling med protonpumpehemmere.

Legemiddelprodusenter kan fange opp artikler som denne i medisinsk litteratur og deretter melde det inn til den norske bivirkningsdatabasen. Det er i 2016 meldt inn ett slikt tilfelle av hypomagnesemi fra en legemiddelprodusent. Det er imidlertid å foretrekke at mistenkte bivirkninger meldes inn direkte fra behandlende helsepersonell. Meldingene inneholder da ofte mer fullstendig informasjon og melderen kan kontaktes ved eventuelle spørsmål.

Helsepersonell melder bivirkninger til RELIS i sin helseregion ved mistanke om sammenheng mellom en reaksjon og et legemiddel. Bivirkningsmeldingene er en viktig del av overvåkingen som pågår gjennom hele livssyklusen til legemidlene. Spontanrapporteringssystemet er helt avhengig av meldevillighet fra helsepersonell. Det er et kjent fenomen over hele verden at legemiddelbivirkninger underrapporteres. Konsekvensen av dette kan være redusert pasientsikkerhet, fordi myndighetene ikke kan reagere med forebyggende tiltak mot et sikkerhetsproblem de ikke er kjent med (3).

\section{Erlend Aa \\ erlend.aa@legemidler.no \\ Ane S. Simensen}

Erlend Aa (f. 1978) er cand.pharm. og legemiddelrådgiver ved RELIS Midt-Norge.

Ingen oppgitte interessekonflikter.

Ane S. Simensen (f. 1984) er forsker ved Seksjon for legemiddelovervåking, Statens legemiddelverk.

Ingen oppgitte interessekonflikter.

\section{Litteratur}

1. Bruserud $\emptyset$. Hansen B-A. Magnesiummangel og protonpumpehemmere. Tidsskr Nor Legeforen 2016; 136: 1336.

2. Aa E. Hypomagnesemi ved bruk av protonpumpehemmere. https://relis.no/ Bivirkninger/Nytt_om_bivirkninger/2011/

Hypomagnesemi ved bruk av protonpumpehemmere/ (5.9.2016).

3. Statens legemiddelverk. Bivirkningsmelding for helsepersonell. www.legemiddelverket.no/Bivirkninger/Meld_bivirkninger/ helsepersonellmelding/ (24.8.2016).

\section{$\emptyset$. Bruserud \& B.A. Hansen svarer:}

Vi vil takke Aa \& Simensen for deres kommentar (1) til vårt innlegg i Tidsskriftet om magnesiummangel og protonpumpehemmere. De kommer med relevant og oppdatert tilleggsinformasjon om det omtalte tema, og minner samtidig om helsepersonells meldeplikt til RELIS om alvorlige legemiddelreaksjoner. Et velfungerende rapporteringssystem er helsepersonells kollektive ansvar og kan være avgjørende for god medisinsk behandling og pasientsikkerhet. Dessverre er det likevel velkjent at legemiddelbivirkninger underrapporteres. Helsepersonell burde generelt være mer oppmerksom på dette - oss selv inkludert! Tilfellet til vår kasuistikkpasient er nå meldt i RELIS, og vi beklager sterkt denne forsinkelsen.

Øyvind Bruserud

oyvind.bruserud@uib.no

Bent-Are Hansen

Øyvind Bruserud (f. 1985) er lege og ph.d.-stipendiat ved Klinisk institutt 2, Universitetet i Bergen.

Ingen oppgitte interessekonflikter. 
Bent-Are Hansen (f. 1984) er lege i spesialisering ved Medisinsk avdeling, Haukeland universitetssykehus.

Ingen oppgitte interessekonflikter.

\author{
Litteratur \\ 1. Aa E, Simensen ASRE. Magnesiummangel og protonpumpehemmere. Tidsskr \\ Nor Legeforen 2016; 136: 1336.
}

\section{Re: Vi skal alle gjøre feil}

Semesterstart er som kjent tiden for de store, høytsvevende visjoner. Denne gangen er det Petter Gjersvik som er ute og svinger pennen (1). Han har selvfølgelig rett når han skriver at «tilbakemeldinger på egne prestasjoner og handlinger er avgjørende for god læring.» Problemet er at han fremstiller det som om vi studenter ikke ser verdien av kritikk, eller for å bruke hans ord, at vi foretrekker «passiv mating av fakta.»

Realiteten er at vi tørster etter flere og bedre tilbakemeldinger på studiet. De er nemlig tilnærmet fraværende. Da vi startet på medisinstudiet ble vi overrasket over hvor udelt positive legene var til våre famlende forsøk på anamnese og undersøkelse. Vi tenkte at det ville endre seg utover i studiet, at vi etterhvert ville bli behandlet som voksne mennesker som tålte ærlige tilbakemeldinger, på godt og vondt. At vi ville bli stilt krav til.

Fem år senere har vi fortsatt til gode - med noen få hederlige unnta - å oppleve dette. Å stille uforberedt til undervisning er ikke noe problem ved medisinstudiet i Oslo. Underviserne er så redde for å tråkke på studentenes tær, at man slipper unna med tilnærmet hva som helst. Det motiverer ikke, og det fremmer ikke faglig utvikling.

Det er tydelig at Gjersvik og fakultetet har fått med seg at vi trenger mer tilbakemeldinger. Problemet er bare at løsningen deres er helt feil. Tendensen til å innføre stadig flere obligatoriske presentasjoner for studentene er kun et behagelig blindspor for underviserne. Når studentene klager over at det kaster bort tiden vår, er ikke det fordi vi er late, det er fordi vi lærer lite av det. Å lese opp fire forberedte setninger om veneriske sykdommer gjør oss ikke til bedre leger.

Karakterer er fakultetets andre svar. Det kan godt hende at vi vil lese mer, men våre kliniske kommunikasjonsferdigheter, vår undersøkelsesteknikk og vår evne til kritisk resonnering rundt komplekse sykdomsbilder, blir ikke bedre. Det er bare tilbakemeldinger i klinisk praksis som kan fylle dette tomrommet. Kanskje skulle både studenter og undervisere hatt opplæring i hvordan man gir og mottar konkret og berettiget tilbakemelding (2).

Kjære fremtidige kolleger. Fortell oss hva vi kan bli bedre på, og si ifra når det vi gjør ikke er godt nok. Vi ønsker å kjenne på skammen og flauheten ved å få påpekt feil. Vi vil kjenne på det så mange ganger, at den dagen vi faktisk gjør en feil som teller, så er vi leger nok til å innrømme det.

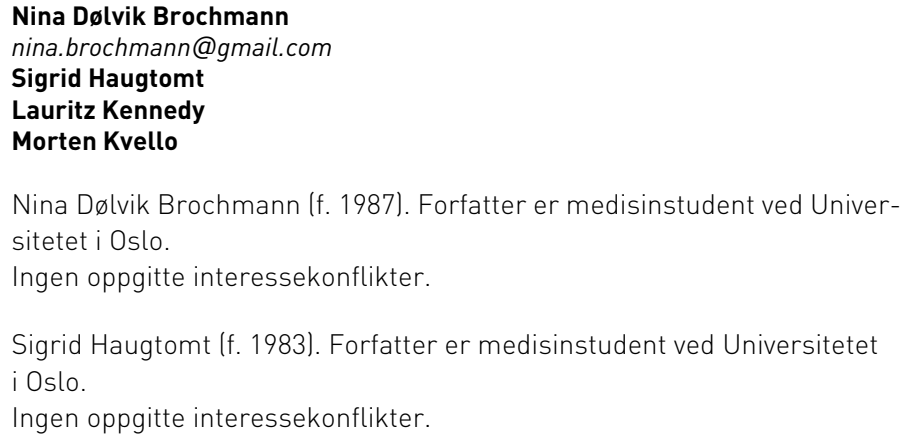

Nina Dølvik Brochmann (f. 1987). Forfatter er medisinstudent ved Universitetet i Oslo.

Ingen oppgitte interessekonflikter.

Sigrid Haugtomt (f. 1983). Forfatter er medisinstudent ved Universitetet i Oslo.

Ingen oppgitte interessekonflikter.

Lauritz Kennedy (f. 1987). Forfatter er medisinstudent ved Universitetet i Oslo.

Ingen oppgitte interessekonflikter.

Morten Kvello (f. 1991). Forfatter er medisinstudent ved Universitetet i Oslo.

Ingen oppgitte interessekonflikter

\section{Litteratur}

1. Gjersvik P. Vi skal alle gjøre feil. Tidsskr Nor Legeforen 2016; 136: 1179

2. van de Ridder JM, Stokking KM, McGaghie WC et al. What is feedback in clinical education? Med Educ 2008; 42: 189-97.

\section{P. Gjersvik svarer:}

Takk til Brochmann og medarbeidere for et tankevekkende innlegg. De har et klart og utvetydig budskap til oss lærere: Vi svikter studentene når vi ikke gir dem tilbakemeldinger i undervisningen. Dette er kritikk vi må ta på alvor. Her har lærere og fakultetsledelse en jobb å gjøre.

Når det gjelder opplegget med studentforberedt undervisning, som vi har praktisert i faget hud- og veneriske sykdommer i Oslo de siste årene, er det mer uklart hva de mener. Deres utsagn om «å lese opp fire forberedte setninger om veneriske sykdommer» er ikke representativt. Vi har faktisk aldri brukt et venerologisk emne til denne undervisningen.

At studenter og lærere har ulikt syn på eksamen og karakterer, er ikke noe nytt. Man kan mislike det, men det er liten tvil om at eksamen og karakterer i stor grad er styrende for studentenes studieatferd. Og eksamen skal ikke bare teste kunnskap, slik Brochmann og medarbeidere synes å mene, men også evnen til kommunikasjon, pasientundersøkelse og klinisk resonnement.

Brochmann og medarbeidere foreslår at studenter og undervisere bør få opplæring i hvordan man gir og mottar tilbakemeldinger. Dette er et godt forslag som studieledelsen ved fakultetene bør vurdere.

\section{Petter Gjersvik}

petter.gjersvik@medisin.uio.no

Petter Gjersvik (f. 1952) er medisinsk redaktør i Tidsskriftet, førsteamanuensis og undervisningsleder i hud-og veneriske sykdommer ved Universitetet i Oslo.

Ingen oppgitte interessekonflikter.

\section{Re: Medikamentetterlevelse og monitorering av antihypertensiv behandling}

Takk for en meget interessant og relevant oversiktsartikkel, der en blant annet omtaler nytten av terapeutisk legemiddelmonitorering som virkemiddel for å fremme legemiddeletterlevelse hos pasienter som behandles med antihypertensiva (1). Behov for kontroll av legemiddeletterlevelse (compliance) er en av flere kliniske situasjoner der terapeutisk legemiddelmonitorering kan være indisert (2).

Samtidig vil jeg benytte anledningen til å minne om at analyserepertoaret ved mange av landets 50 laboratorier endres raskt (3), og at Norsk forening for klinisk farmakologi derfor i mars 2015 lanserte Farmakologiportalen, fagmiljøets egen oversikt over slike analyser (4). Her finner man en felles oppdatert farmakologisk analyseoversikt for norske laboratorier, med både søkefunksjon og listevisning for substanser, laboratorier og fagstoff. Slik kan man til enhver tid finne ut hvilke legemiddel- og rusmiddelanalyser som tilbys, og hvor. 